\title{
Land Capability and Suitability Assessment for Sweet Potato (ipomoea batatas 1.) in Cimanggung Sub District, Citarik Sub watershed, West Java
}

\author{
Rina Devnita1, Marenda Ishak Sonjaya Sule1), Cucu Suherman², Apong Sandrawati1), \\ Widara Almaghfirah Ismail1) \\ ${ }^{1}$ Soil Science Departement, Faculty of Agriculture, Universitas Padjadjaran \\ ${ }^{2}$ Agronomy Departement, Faculty of Agriculture, Universitas Padjadjaran \\ Korespondensi: rina.devnita@unpad.ac.id
}

\begin{abstract}
Cimanggung Sub District, located in the area of Citarik Sub Watershed, West Java, Indonesia, is one of important watershed that support life and water need. However, the pollution in this sub watershed is high, degraded the environment. Therefore, the agricultural management must be suitable with land capabilty and land suitability. The objective of this resarch was to evaluate the land capability and suitability for sweet potato (Ipomoea batatas, L). The assessment used the limiting factor for land capability and matching table for land suitability. The results showed that the Cimanggung Sub District consisted of 13 land mapping unit (LMU) with land capability classes: II- L2, $\mathrm{E}_{1}, \mathrm{R}_{1}$, LMU 8; III-P4, LMU 10; IV- L3, KE 6 , LMU 1, 2, 4, 6, 9, 12 and 13; VI-L4, LMU 5 and 7; VII15, LMU 3 and11. Areas suitable for agriculture were classes II, III, and IV (LMU 8, 10, 1, 2, 4, 6, 9, 12 and 13) and the areas non suitable for agriculture were classes VI and VII (LMU 5, 7 and 3). The actual land suitability for Cilembu sweet potato was S3 at LMU 8 and 10 and N1 at LMU 1, 2, 4, 6, 9, 12 , and 13 with the main limiting factors were nutrient retention and rooting zone. Liming is the management that can be used to improve potential land suitability to LMU 1, 2, 4, 6, 12 and 13, which improve Nnr to S3nr, and to LMU 8 and 10, improve S3nr to S2nr. Clay fraction limiting factor in LMU 9 was irreparable.
\end{abstract}

Keywords: agricultural management, land assesment, sweet potato, limiting factors.

\section{INTRODUCTION}

Citarik Sub Watershed is part of Upper Citarum Watershed, one of the longest (297 km) and largest $\left(11,324 \mathrm{~km}^{2}\right)$ watershed in Java (Sahu et. al., 2011). It is administratively located in Sumedang Regency, West Java Province, Indonesia. It has important function as water source, and therefore supporting the water need in this area. However, the waste pollution in the surrounding is also high, degraded the resources of ecosystem (Sholeh et al., 2018). This sub watershed area must be managed properly to keep it environment ecofriendly.

Cimanggung is one of the Sub District located in the Citarik Sub Watershed. Agricultural management is one thing that must be considered in Cimanggung Sub District, cover the area with appropriate plants, prevent bare land that cause erosion. The decision of suitable crop must cosider the land capability and land suitability. Look to the adjacent area, the neighbourhood Sub District is used to grow Cilembu sweet potato (Ipomoea batatas L). This favour and qualified sweet potato has not been grown in Cimanggung Sub District. The farmers in this area have no effort yet to cultivate their farm with this high economically crop. Land evaluation therefore is important and needed to know the potentiality of this area and to manage land productivity optimizely (Mehrjardi et al, 2020). This is one approach to assess land potentiality as a sustainability using.

Cilembu sweet potato is a sweet potato that specific in Cilembu village, the adjacent area to Cimanggung Sub District. It has a special sweet honey taste (Anda et al, 2018), and the sweetness quality fulfill the requirements of export standard (Agustina and Erwina, 2016). This sweet potato supplies market in several countries like Japan, Singapore, South Korea 
(Hoeridah and Sarianti, 2011). It actually growth exclusively in the Cilembu Village, but the hybrid of Cilembu sweet potato has almost same quality with a wider adaptability if cultivated in the area around Cilembu (Solihin et. al., 2018).

\section{METODH}

The summarize of the methodology in this research and the sources of data and processing is presented in Figure 1. This research used several materials like maps, field equipments and laboratory instruments. Maps used were administrative map of Cimanggung Sub District, rainfall map, land used map, topographical map and soil map. Some field equipments used were GPS (global postioning system), clinometer, auger, ring sampler, Munsell Soil Color Chart Book, and other common field things.

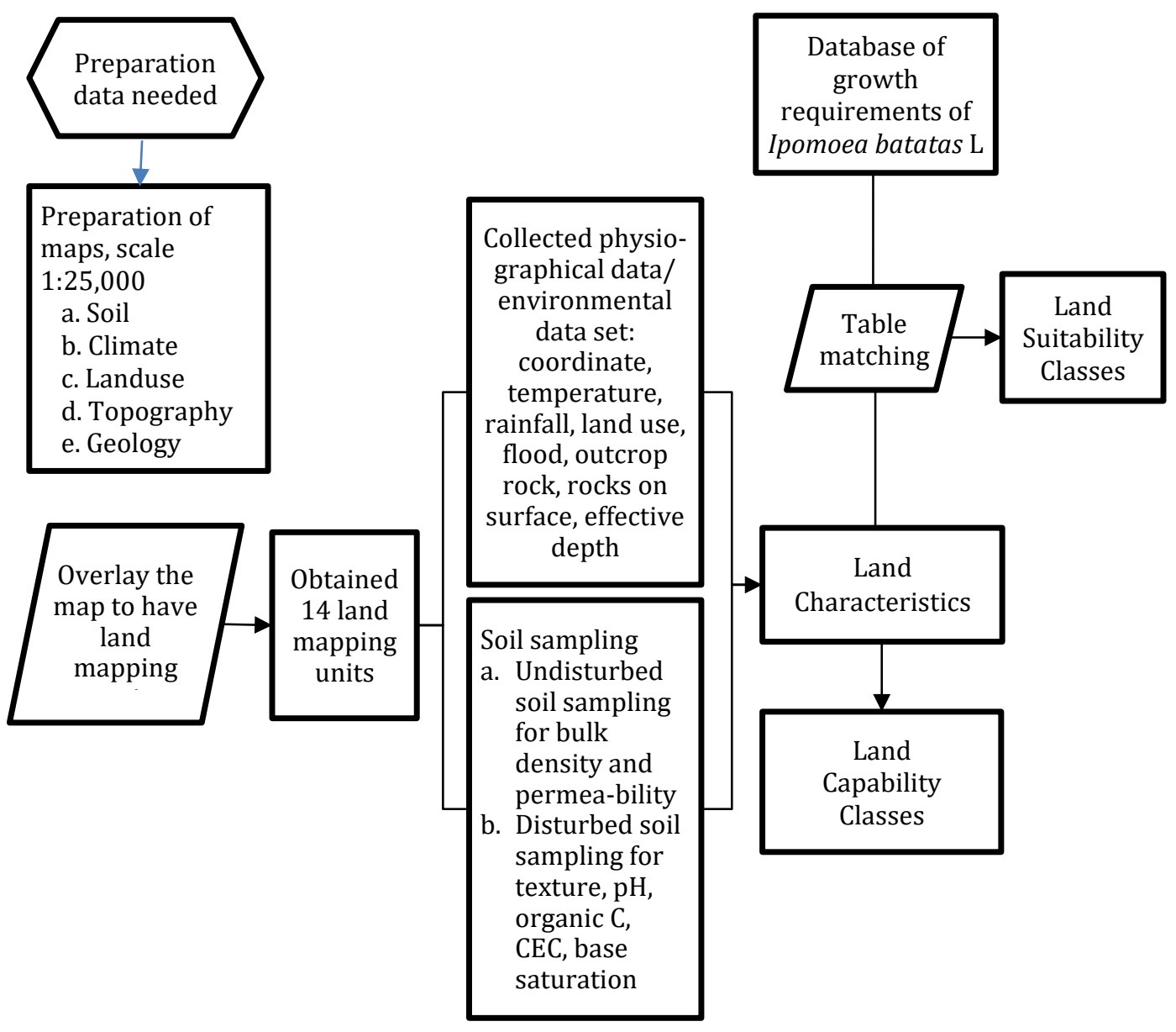

Figure 1. The scheme of data source and step of processing

Instruments used in laboratory and workshop were $\mathrm{pH}$ meter (measuring $\mathrm{pH}$ ), AAS (measuring CEC and base saturation), combustions (measuring organic $\mathrm{C}$ ), oven (measuring bulk density), circulating watersupply system (measuring permeability). analytic scale, sieving (measuring texture), EC meter (measuring salinity) and and Arc Gis 10.6.1 (processing maps).

The method used was a descriptive and explorative, approaching to land mapping units obtained from overlaying maps to have appropriate landmapping units with the similarity of several characteristics. Soil 
sampling were done to representative land mapping unit.

Soil samples were taken in every land mapping unit in several spots and be mixed compositely to homogenise further to be analysed chemical and physical characteristics. Soil samples were taken disturbed to the depth of $30 \mathrm{~cm}$ for analysing $\mathrm{pH}$, organic $\mathrm{C}, \mathrm{CEC}$, base saturation, salinity, and texture by referred to Van Reeuwijk (1982). Soil samples were taken undisturbed with ring samplers for analysing bulk density and permeability by referred to Klute and Dirksen (1986).

Data analyses were done for detemining land capabilitiy classes by determined the inhibiting factors and be sequentially from small and few inhibiting factors (Class I) to large and many inhibiting factors (Class VIII) referered to Verheye (2009). Environment and soil data resulted in land characteristics. These characteristics will then be matched with plant growth requirements of sweet potato mentioned by Solihin (2018) for determining actual land suitabilty classes. The actual land suitabilty will then can be improve to potential land suitability if the inhibiting factors can be overcames.

\section{RESULT AND DISCUSSION}

Cimanggung district in Citarik sub watershed located at the elevation of 683 to $1,110 \mathrm{~m}$ above sea level (asl) covers the area of 4,265 ha. The location of Cimanggung Sub Distric, Citarik Sub Waterhed in West Java Province, Indonesia is presented in Fig 2. Only a very few parts of this area can be used for agriculture, due to most of them are very steep as an arable land. Among the flat or rather flat area, that can be used as agriculture area devided into wet land farming for paddy field (9.21 ha) and dry land farming for horticulture (23.9 ha) as informed by Statistic Indonesia (2018).

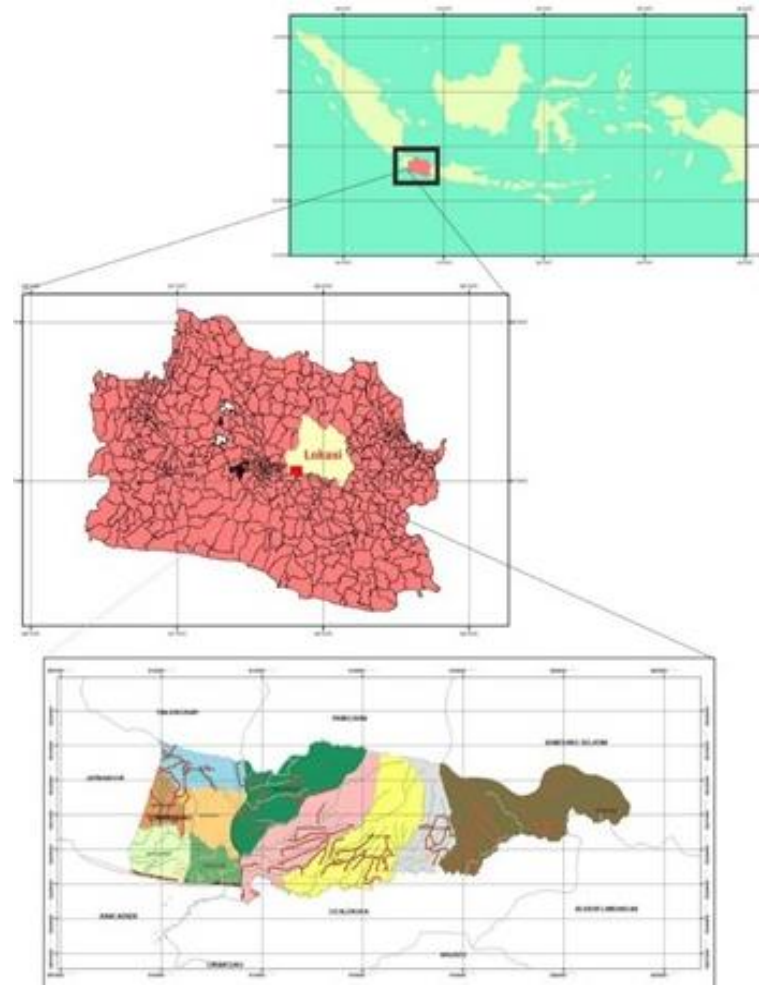

Figure 2. Map of Cimanggu Sub District, West Java Province, Indonesia

\subsection{Land Capability Analyses}

Land capability analyses were done based on the field and laboratory data. Field data covered climate, slope, potential and factual erotion, effective soil depth, drainage, permeability, outcrop rock, rock on surface, flooding and salinity (Verheye, 2009; Constantini, 2017). Monthly annual rainfall average is presented in Figure 3. Average rainfall map is presented in Figure 4.

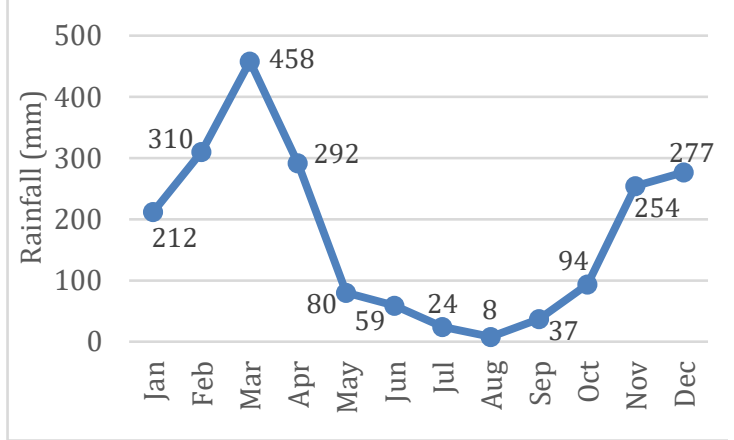

Figure 3 Monthly annual rainfall average in Cimanggung Subdistrict (2014 2019) 


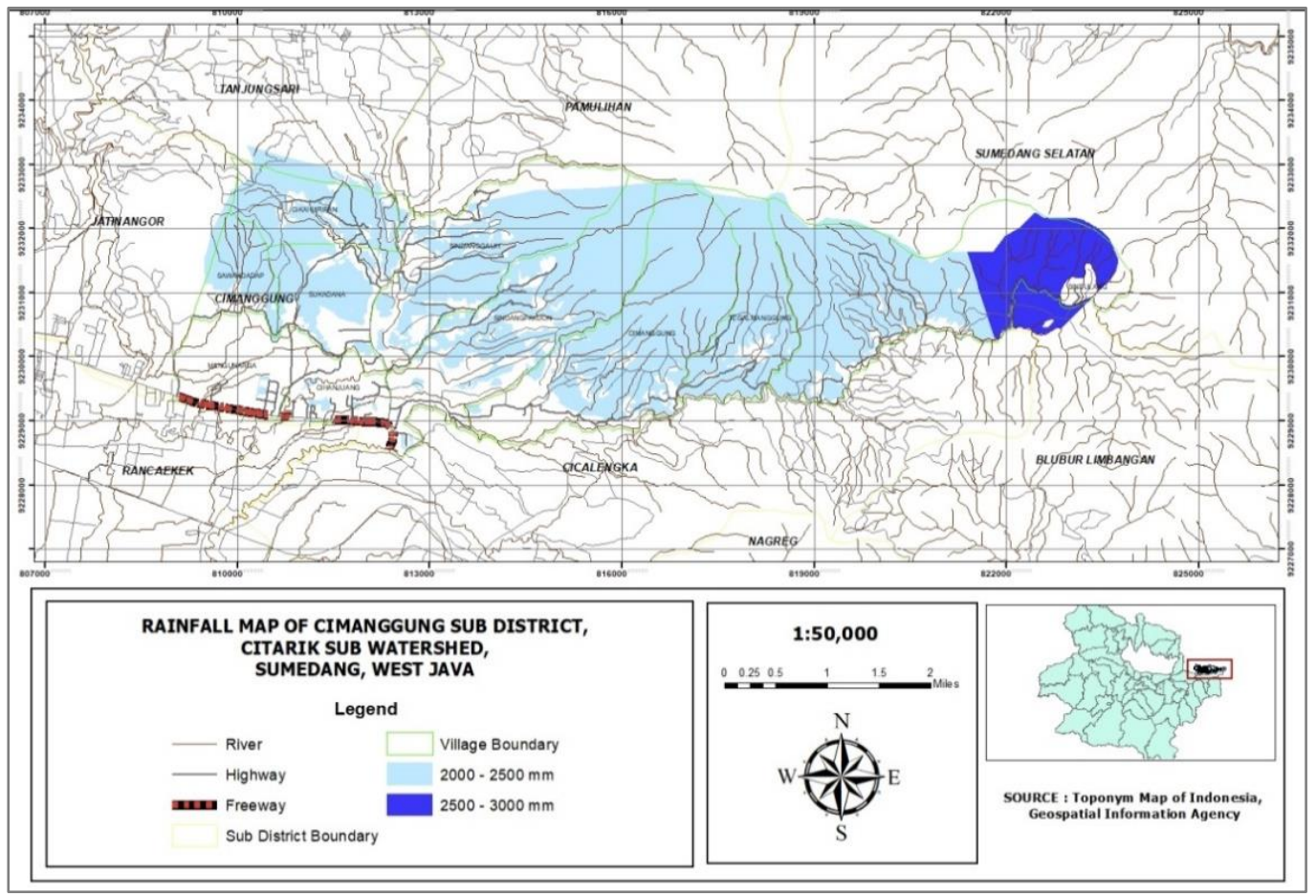

Figure 4 Average annual rainfall map

The temperature in this area range from 19.5 to $22.1{ }^{\circ} \mathrm{C}$ with the annual average of 20.8 ${ }^{\circ} \mathrm{C}$. The annual rainfall is $2105 \mathrm{~mm}$ year ${ }^{-1}$ with maximum (458 $\mathrm{mm}$ ) fall in March and minumum (8mm) fall in August. There are six months succesively from November to April where the rainfall are more than $200 \mathrm{~mm}$ month $^{-1}$ and another six months from April to October the monthly rainfall is lower than 100 mm month ${ }^{-1}$. Refered to Oldeman (1982) this area is C3 type, and crop rotation of rice and horticulture periodically once a year.

Some field and laboratory data of land characteristic presented in Table 1. Land characteristics informed that the slope of Cimanggung District was range from flat $(1 \%$, land mapping unit 10) to steep (55\%, land mapping unit 3). Others land mapping unit had wavy and hilly slope.

Table 1. Land characteristic of Cimanggung District

\begin{tabular}{ccccccc}
\hline $\begin{array}{c}\text { Land } \\
\text { Mapping } \\
\text { Unit }\end{array}$ & $\begin{array}{c}\text { Land } \\
\text { Use }\end{array}$ & $\begin{array}{c}\text { Slope } \\
\%\end{array}$ & Texture & $\begin{array}{c}\text { Permeabily } \\
\text { cm hour- }\end{array}$ & $\begin{array}{c}\text { Erodiblity } \\
(\mathrm{K})\end{array}$ & $\begin{array}{c}\text { Salinity } \\
\text { mmhos }\end{array}$ \\
\hline 1 & Moor & 17 & Silty loam & 8,94 & 0,59 & 0,014 \\
2 & Moor & 16 & Clay & 6,08 & 0,04 & 0,017 \\
3 & Moor & 55 & Silty clay & 8,29 & 0,15 & 0,012 \\
4 & Moor & 30 & Silty loam & 7,32 & 0,45 & 0,020 \\
5 & Shrubs & 35 & Silty clay & 4,58 & 0,13 & 0,023 \\
6 & Moor & 25 & Clay & 3,8 & 0,04 & 0,016 \\
7 & Moor & 35 & Silty clay & 5,74 & 0,19 & 0,035 \\
8 & Moor & 6 & Silty clay & 4,34 & 0,14 & 0,028 \\
9 & Moor & 6 & Silty loam & 5,77 & 0,58 & 0,018 \\
10 & Shrub & 1 & Silty clay loam & 7,31 & 0,24 & 0,038 \\
11 & Moor & 49 & Loam & 3,37 & 0,37 & 0,018 \\
12 & Moor & 25 & Clay & 5,64 & 0,04 & 0,019 \\
13 & Garden & 23 & Clay & 8,5 & 0,02 & 0,015 \\
\hline
\end{tabular}


The erosion rate was slight (less than 25\% of top soil loss). Regarding to soil erodibilty (K), the calculation had been done using the formulation by Wischmeier and Smith (1978) resulted in highest $\mathrm{K}$ value $(0.59$, land mapping unit 1$)$ to the lowest (0.02, land mapping unit 13). Efective soil depth was $60 \mathrm{~cm}$ or more. No mottling found from the top soil to the $60 \mathrm{~cm}$ depth, informed that the drainage was good, and permeability was quick (3.58-8.94 $\mathrm{cm}^{\text {hour-1)}}$ ). Quick permeablity impacted to flooding, where there was no flood that more than 24 hours in this area (threat of flooding was zero). There was no outcrop rock and very few gravels in certain area (less than 15\%). The whole area was free from salinity (less than 4).

Considering all data needed for classifying land capability in Cimanggung Sub District of Citarik Sub Watershed by taking into account the limiting/inhibiting factors found in the area like slope, erosivity, outcrop rock, rock in the surface, erodibility, and permeability, the area can be devided into five classes as described in Table 2 and Figure 5. Slope (L) is one of limiting factor that found in all land mapping unit (except land mapping unit 10) and in all class of Land Capability Classes (except III P4).

Table 2 Land Capability Classes at Cimanggung District

\begin{tabular}{|c|c|c|c|c|}
\hline \multirow[b]{2}{*}{ No } & Land & \multirow{2}{*}{$\begin{array}{l}\text { Land mapping } \\
\text { unit }\end{array}$} & \multicolumn{2}{|c|}{ Area } \\
\hline & $\begin{array}{c}\text { Capability } \\
\text { Classes }\end{array}$ & & Hectar & $\%$ \\
\hline 1 & II- $\mathrm{L}_{2}, \mathrm{E}_{1}, \mathrm{R}_{1}$ & 8 & 2.57 & 0.11 \\
\hline 2 & III-P 4 & 10 & 8.34 & 0.36 \\
\hline 3 & IV- $\mathrm{L}_{3}, \mathrm{KE}_{6}$ & $1,2,4,6,9,12,13$ & 1462.87 & 63.57 \\
\hline 4 & VI- $\mathrm{L}_{4}$ & 5,7 & 383.53 & 16.66 \\
\hline 5 & VII- L5 & 3,11 & 444.18 & 19.30 \\
\hline & \multicolumn{2}{|c|}{ Total area } & 2301.49 & 100 \\
\hline
\end{tabular}

Notes: Roman number indicated land capability classes, latin letters indicated inhibiting factors and latin numbers indicate the level of inhibiting factors. L Slope, KE: Erodibilty, R: rock on surface, E: degree of erosion, P: Permeability.

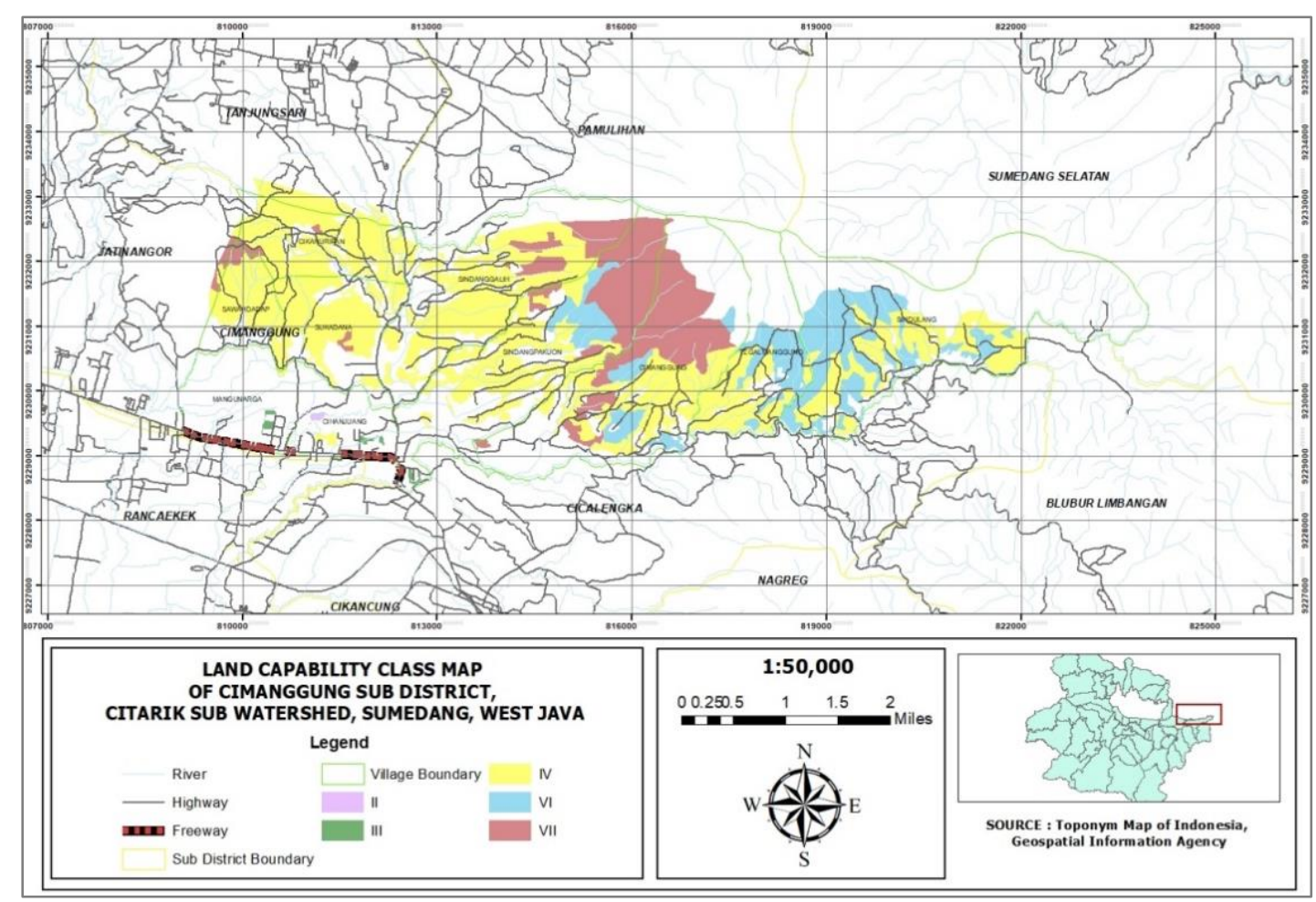

Figure 5 Land Capabilty Classes Map

\subsection{Land Suitability Analyses}

Land suitability analyses were done by matching the land characteristics with criteria of growth requirements of sweet potato. The assesment of land suitability was taking into account the limiting factor in every land 
mapping unit. Parameter with lowest suitablity will be taken as the class of land suitability at representative area. Parameter with higher or highest suitability in the other hand are not the consideration in determining land suitability.

\subsubsection{Actual Land Suitability}

The criteria of very suitable (S1) cover the average temperature $\left(21,7-24,6^{\circ} \mathrm{C}\right)$, rainfall at third and fourth month after planting (152,5$423 \mathrm{~mm}$ and 133,2-443,7 $\mathrm{mm}$ ), percentage of clay fraction (44-56\%) and sand fraction $(6,29 \%)$, efective soil depth $(>91,4 \mathrm{~cm})$, cation exchange capacity $(>21.9 \mathrm{cmol} \mathrm{kg}-1)$, base saturation $(44,7-83,7 \%), \mathrm{pH}_{\text {water }}(6,30-7,40)$, organic C $(0,9-1,9 \%)$, rock on the surface $<<$ $3.4 \%)$, and outcrop rock $(<1.1 \%)$ as mentioned by Solihin (2018). Other value higher or lower than these values will be classed as S2 (suitable), S3 (marginal suitable), N1 (non suitable for this moment) or N2 (non suitable forever), depend on how much or how far the difference with the criteria to S1 (Verheye, 2009; Constantini, 2017).

The temperature in this area ranged from 19.5 to $22.1{ }^{\circ} \mathrm{C}$ with the annual average of 20.8 ${ }^{\circ} \mathrm{C}$. The annual rainfall was $2105 \mathrm{~mm}$ year-1 with maximum (458 $\mathrm{mm}$ ) fall in March and minumum (8mm) fall in August. There were six months succesively from November to April where the rainfals were more than $200 \mathrm{~mm}$ month $^{-1}$ and another six months from April to October where the monthly rainfall were lower than $100 \mathrm{~mm} \mathrm{month}^{-1}$. The rainfall requirements for the third and fourth months in the criteria of land characteristics aimed to to determine the beginning of the best planting period, to have enough water content in that month. It should not too high, causing decreasing the sugar content in sweet potato or too low, causing lacking water. Average temperature in the area were same $\left(20.8^{\circ} \mathrm{C}\right)$ and were classified as S2. The rainfall of the third and fourth month can be managed by adjusted the proper month to start planting.

The comprehensive analyses result of land characteristics is presented in Table 3. Effective soil depth $(60 \mathrm{~cm})$, rock on surface $(<5 \%)$ and outcrop rock $(<5 \%)$ found in whole land mapping units and were classified as S1, therefore will not be limiting factors in this district refered to Solihin (2018). Actual land suitability based on the actual land condition therefore can be seen in Table 3 and the map is presented in Figure 6.

Table 3 Land Suitability (LS) in every Land Mapping Unit (LMU)

\begin{tabular}{|c|c|c|c|c|c|c|c|c|c|c|c|c|c|c|}
\hline \multirow[b]{2}{*}{ LMU } & \multicolumn{4}{|c|}{ Root Zone (rc) } & \multicolumn{8}{|c|}{ Nutrient Retentention (nr) } & \multicolumn{2}{|c|}{ Land Suitability } \\
\hline & $\begin{array}{c}\text { Clay } \\
\%\end{array}$ & LS & $\begin{array}{c}\text { Sand } \\
\%\end{array}$ & LS & $\mathrm{CEC}$ & LS & $\begin{array}{l}\mathrm{BS} \\
\%\end{array}$ & LS & $\mathrm{pH}_{\mathrm{w}}$ & LS & $\begin{array}{c}\text { Org.C } \\
\%\end{array}$ & LS & Actual & Potential \\
\hline 1 & 60,47 & S2 & 26,03 & S1 & 25,39 & S3 & 26,06 & S3 & 4,4 & $\mathrm{~N}$ & 0,83 & S1 & $\mathrm{Nnr}$ & S3nr \\
\hline 2 & 37,2 & S2 & 16,8 & S1 & 34,23 & S3 & 27,60 & S3 & 4,2 & $\mathrm{~N}$ & 1,84 & S1 & $\mathrm{Nnr}$ & S3nr \\
\hline 4 & 62,41 & S2 & 22,59 & S1 & 33,42 & S3 & 14,96 & S3 & 4,4 & $\mathrm{~N}$ & 2,17 & S2 & $\mathrm{Nnr}$ & S3nr \\
\hline 6 & 26,2 & S2 & 2,3 & S3 & 25,71 & S1 & 20,92 & S1 & 3,8 & $\mathrm{~N}$ & 1,30 & S1 & $\mathrm{Nnr}$ & S3nr \\
\hline 8 & 49,62 & S1 & 3,38 & S2 & 39,54 & S1 & 63,17 & S1 & 5,2 & S3 & 2,04 & S2 & S3nr & $\mathrm{S} 2 \mathrm{nr}$ \\
\hline 9 & 76,39 & $\mathrm{~N}$ & 10,11 & S1 & 25,38 & S1 & 51,29 & S1 & 5.0 & S3 & 1,11 & S1 & $\mathrm{Nrc}$ & $\mathrm{Nrc}$ \\
\hline 10 & 54,71 & S1 & 9,79 & S1 & 36,92 & S1 & 46,60 & S1 & 5.0 & S3 & 2,03 & S2 & S3nr & S2nr \\
\hline 12 & 34,58 & S2 & 8,92 & S1 & 28,40 & S2 & 30,37 & S2 & 4,3 & $\mathrm{~N}$ & 1,09 & S1 & $\mathrm{Nnr}$ & S3nr \\
\hline 13 & 26,26 & $\mathrm{~S} 2$ & 13,24 & S1 & 43,14 & S2 & 40,24 & S2 & 4,3 & $\mathrm{~N}$ & 1,44 & S1 & $\mathrm{Nnr}$ & S3nr \\
\hline
\end{tabular}




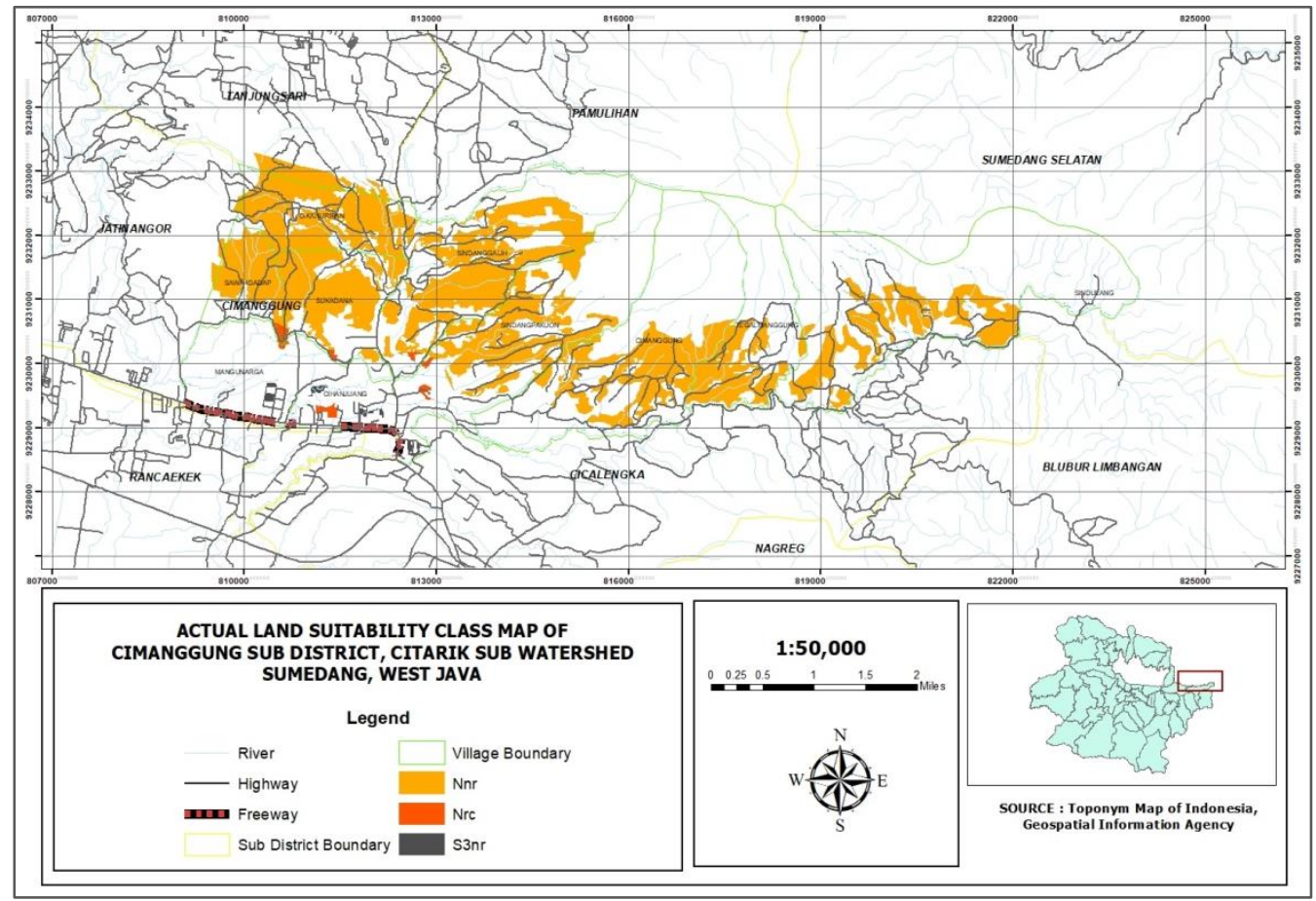

Figure 6 Actual land suitability map

\subsubsection{Potential Land Suitability}

Potential land suitability is obtained by corrected some possible improving from actual land suitability (Costantini, 2017). Low soil pH can be corrected by increasing it with lime (Jaskulska, et al, 2014). Low CEC can be improved by adding organic matter (Liang et al, 2006). However, several limiting factors are diffucult to be fixed. Rainfall, temperature, humidity, texture, steep slope are some limiting factor that difficult to be improved or customized (Sys et al, 1991; Girmay et al, 2018; Kurniawan and Pamungkas, 2020). The complete potential land suitability and the improving is presented in Table 4 .

The limiting factors found in this sub watershed as can be seen in Table 3 were low soil pH (4.4 or lower in land mapping unit 1, 2, $4,6,12,13)$, much lower than that can be allowed (6.3-7.40). These land mapping unit were classified as S3nr. Meanwhile land mapping unit 8 ad 10 had the same similar $\mathrm{pH}$ limiting factor, but the value a little bit higher (5.2 and 5.0) that only 1.3 unit lower than allowed value, and therefore were classified as S2nr.

Table 4 Actual Land Suitability, Improving effort and Potential Land Suitability

\begin{tabular}{ccccc}
\hline LMU & $\begin{array}{c}\text { Actual } \\
\text { Land } \\
\text { Suitability }\end{array}$ & $\begin{array}{c}\text { Improving } \\
\text { Effort }\end{array}$ & $\begin{array}{c}\text { Rate of } \\
\text { Improving }\end{array}$ & $\begin{array}{c}\text { Potential } \\
\text { Land } \\
\text { Suitability }\end{array}$ \\
\hline 1 & $\mathrm{Nnr}$ & Liming & Moderate & S3nr \\
2 & $\mathrm{Nnr}$ & Liming & Moderate & S3nr \\
4 & $\mathrm{Nnr}$ & Liming & Moderate & S3nr \\
6 & $\mathrm{Nnr}$ & Liming & Moderate & S3nr \\
8 & $\mathrm{~S} 3 \mathrm{nr}$ & Liming & Light & S2nr \\
9 & $\mathrm{Nrc}$ & Irreparable & N/A & $\mathrm{Nrc}$ \\
10 & $\mathrm{~S} 3 n r$ & Liming & Light & S2nr \\
12 & $\mathrm{Nnr}$ & Liming & Moderate & S3nr \\
13 & $\mathrm{Nnr}$ & Liming & Moderate & S3nr \\
\hline
\end{tabular}

Another limiting in this area factor was the high clay content (76.3\%; land mapping unit 9), much higher than appropriate one (44-56\%). High dosage of liming can improve land suitablilty in land mapping unit, 2, 4, 6, 12, 13 . Therefore, the land suitability classes increased from Nnr (actual land suitability) to S3nr (potential land suitability). Lower dosage of liming should be corrected the actual land 
suitability classes (S3nr) to S2nr. However, high clay content in land mapping unit 9 can not be fixed and potential land suitability will be same with actual land sitablity. The map of potential land suitability is presented in Figure 7.

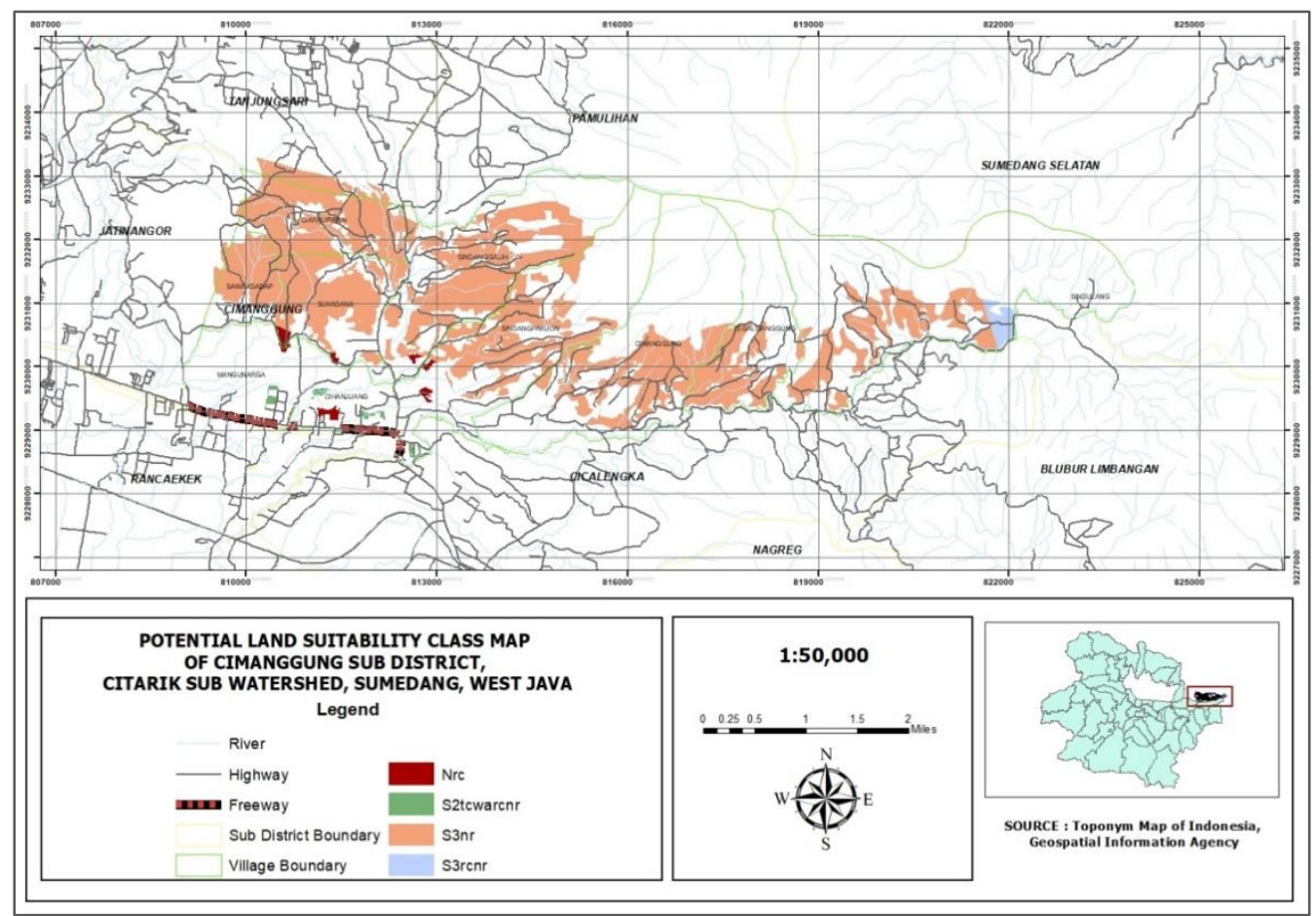

Figure 7 Potential land suitability map

\section{CONCLUSSIONS}

Cimanggung Sub District consisted of 14 land mapping unit with land capability classes: II- $\mathrm{L}_{2}, \mathrm{E}_{1}, \mathrm{R}_{1}$, land mapping unit (LMU) 8; III-P4, LMU 10; IV- $\mathrm{L}_{3}, \mathrm{KE}_{6}$, LMU 1, 2, 4, 6, 9, 12 and 13; VI-L4, LMU 5 and 7; VII-15, LMU 3 and11. Areas suitable for agriculture were the classes of II, III, and IV (LMU 8, 10, 1, 2, 4, 6, 9, 12 and 13) and the areas non suitable for agriculture were the the classes of VI and VII (LMU 5, 7 and 3). The actual land suitability for Cilembu sweet potato was S3 at LMU 8 and 10 and N1 at LMU 1, 2, 4, $6,9,12$, and 13 with the main limiting factors were nutrient retention and rooting zone. Liming is the management that can be used to improve potential land suitability that can be done to LMU 1, 2, 4, 6, 12 and 13, improve Nnr to S3nr, and to LMU 8 and 10, improve S3nr to S2nr. Clay fraction limiting factor in LMU 9 was irreparable.

\section{REFERENCES}

Agustina, S. and W. Erwina. 2016. Marketing of cilembu sweet potato seeds in the cybernetics era through the content of Dongeng Hui Cilembu: a study of ethnostorytelling at Cilembu Village, Sumedang, West Java, Indonesia International Conference of Integrated Microfinance Management. Atlantis Pres.1-6

Anda, M., E. Suryani, Widaningrum and D. Nursyamsi. 2018. Potassium nutrient, temperature and rainfall required to generate 'honey taste' of Cilembu sweet potato. Indonesian Journal of Agricultural Science 19 (1): 33-47.

Costantini, E A.C. 2017. Manual of Methods for Soil and Land Evaluation. CRC Press. $564 \mathrm{p}$

Girmay, G., W. Sebnie1 and Y. Reda. 2018. Land capability classification and suitability assessment for selected crops in 
Gatenowatershed, Ethiopia Cogent Food \& Agriculture 4: 1-18

Hoeridah, A. dan T. Sarianti. 2011. Analisis daya saing ubi jalar Cilembu di Kabupaten Sumedang Jawa Barat. Forum Agribisnis 1 (2): 200-216

Jaskulska, I., D. Jaskulski and M. Kobierski. 2014. Effect of liming on the change of some agrochemical soil properties in a long-term fertilization experiment. Plant Soil Environ. 60 (4): $146-150$

Klute, A, C. Dirksen. 1986. Hydraulic conductivity and diffusivity, laboratory method. Agron. Monogram 9:687-734

Kurniawan, H. and D. Pamungkas. 2020. The limiting factors of land suitability for sandalwood (Santalum album) in Sumba Island, Indonesia. Biodversitas. 21(7): 3364-337 DOI: $10.13057 /$ biodiv/d210761

Liang, B., J. Lehmann, D. Solomon and E. G Neves. 2006. Black Carbon Increases Cation Exchange Capacity in Soils. Soil Science Society of America Journal. 70:1719-1730

Mehrjardi, R. T., K. Nabiollahi, L. Rasoli, R. Kerry and T. Scholten. 2020, Land Suitability Assessment and Agricultural Production Sustainability Using Machine Learning Models. Agronomy 10 (573) 1-20

Sahu, N., Y. Yamashiki, K. Takara and R.B. Singh. 2011. An observation on the relationship between climate variability modes and river discharges of the Citarum Basin, Indonesia. Annuals of Disas. Prev. Res. Inst., Kyoto Univ., No. 54 B. 49-54
Sholeh, M., P. Pranoto, S. Budiastuti and S. Sutarno. 2018. Analysis of Citarum River pollution indicator using chemical, physical, and bacteriological methods. AIP Conference Proceedings.

Solihin, M. A., S.R.P. Sitorus, A. Sutandi and Widiatmaka. 2018. Discriminating Land Characteristics of Yield and Total Sugar Content Classesof Cilembu Sweet Potato (Ipomoea batatas L.). Agrivita Journal of Agricultural Science. 2018. 40 (1): 15-24

Statistics Indonesia. 2018. Cimanggung Sub District in Figures 2018. Statistics of Sumedang District. Catalog Statistic Indonesa: 1102001.3211020 (in Indonesian)

Sys, C., E. Van Ranst and J. Debavey. 1991. Land evaluation. Part I: Principles in land evaluation and crop production calculations. Brussels, Belgium: Agricultural Publications nr. 7, GADC.

Van Reeuwijk, L. P. 1992. Procedure for Soil Analysis. Fourth Edition. ISRIC. Wageningen. The Netherland. $56 \mathrm{p}$

Verheye, W. H. 2009. Land Use, Land Cover and Soil Sciences Vol II: Land Evaluation. Encyclopedia of life support systems (Eolss) Publisher Co. Ltd., Oxford, United Kingdom.

Wischmeier, W.H and D.D Smith. 1978. Predicting rainfall erosion losses-a guide to conservation 236 planning. United States Department of Agriculture Agricultural Handbook, 537 US 237 Government Printing Office, Washington, DC, USA. 